\title{
AIDS and globalisation
}

Why do $95 \%$ of the estimated 33 million people infected with HIV live in the developing world? And why are low income (gross domestic product), unequal distribution of wealth (Gini coefficient), and sex inequality strongly associated with HIV prevalence ${ }^{1}$ It may be argued that this confluence is coincidental. The maturity of the epidemic, different sexual practices, or biology explain why subSaharan Africa is home to the highest HIV rates. The fact that two thirds of the world's poorest countries are also there is a mere accident. Yet this approach ignores the current explosive epidemics in South East Asia and eastern Europe. Clearly there is no simple equation of poverty and HIV prevalence; rather a combination of conditions making a population susceptible to the HIV epidemic and vulnerable to its effects. ${ }^{2}$ Without resorting to economic determinism we wish to pose questions regarding the complex interplay between uncontrolled globalisation of capital and factors that render a population susceptible to HIV.

HIV, especially in the early stages of the epidemic, spreads through commercial sex, injecting drug use, and along the routes of population movement-migration of labour, urban-rural migration, trucking, drug smuggling, and regional wars. This is exacerbated by poor access to information, sexually transmitted disease (STD) treatment, and the low status of women.

The temporal and spatial pattern of the more mature African epidemic matches the migrant labour patterns. In 1989 Hunt hypothesised that the virus spread from labour concentration areas to the migrant labour host communities. $^{3}$ The highest HIV prevalence rates were in the areas of labour concentration in the Zambian copper belt and Ugandan industrial areas, with lower rates in places that provide the labour force: north east Zambia, Rwanda, Burundi, and south west Uganda. ${ }^{3}$ HIV prevalence rates $2.5-3$ times greater than in non-mobile populations have been found in migrant labourers in Uganda ${ }^{4}$ and the KwaZulu-Natal in South Africa. ${ }^{5}$ A baseline knowledge, attitude, and practice (KAP) study in Lesotho showed that all cases of HIV occurred in villages along the main road. ${ }^{6}$ A similar observation was made in Mwanza. ${ }^{7}$

Men living in single sex hostels, separated from their families, are a feature of the migrant labour that facilitates HIV spread. HIV positive factory workers in Zimbabwe were more likely to live apart from their wives ${ }^{8} 9$ and South African women whose partners spent 10 or fewer nights per month at home had an HIV prevalence of $13.7 \%$ compared with $0 \%$ in those with partners who stayed home longer. ${ }^{5}$ Half a million migrant workers in the South African mines are not allowed to bring their families to the work place. Commercial sex workers (CSWs) arrive on payday at the single sex hostels and average 10 partners per night ${ }^{10}$; the 1 in 40 chance of being killed by rock fall is unlikely to discourage risk taking behaviour. ${ }^{11}$ A camp of as many as 2000 young male migrant workers in an agricultural complex in Cote d'Ivoire is serviced for 2 nights after payday by a convoy of 30-40 CSWs, often brought in by the employer, with a mean of 25 workers each over this period. ${ }^{4}$ Not surprisingly, high rates of HIV have been noted in association with CSWs in Africa. ${ }^{3}{ }^{42}$

In South East Asia and eastern Europe, areas that until 10 years ago were classified as epidemiological pattern 3, the current escalation of HIV infection is associated with the commercial sex industry and injecting drug use. Urban sex workers have HIV infection rates ranging from 20-60\% in parts of Thailand, Burma (Myanmar), Cambodia, and
India, with well described heterosexual transmission from CSWs to men. ${ }^{13-17}$ In Bangkok, HIV rates in injecting drug users (IDU) exploded from $1 \%$ in 1987 to $40 \%$ in $1988 .{ }^{18}$ HIV prevalence of more than $70 \%$ has been reported in the IDU population of Manipur in the north east of India, the bordering area in northern Burma, and the neighbouring province of Yunan (China).$^{1317} 19$ In eastern Europe there has been an estimated fivefold increase in HIV rates between 1995 and 1997 fuelled principally by the intravenous use of narcotic drugs. ${ }^{17} 20$

According to the World Bank the globalisation of capital has characterised the past two decades. This has meant:

- An explosion in global capital flows which now grossly outweighs the trade in goods. A pool of highly mobile money, growing from US $\$ 2$ million million (US trillion) in the 1980 s to the current value of $\$ 20$ million million, ${ }^{21}$ moves across borders in search of the highest short term returns.

- Greater concentration of wealth in fewer hands. One third of all the trade was in parts and components between subsidiaries within transnational companies. ${ }^{21}$ A pertinent example of this concentration of wealth is that 225 individuals have the combined wealth of $47 \%$ of the world's population. ${ }^{22}$

- Increasing urbanisation and labour flexibility and mobility.

Although these processes had already started, the debt crisis in the late 1970s following the rise in interest rates, and the fall in raw commodity export prices during the 1980s, enabled world economic institutions, including the International Monetary Fund (IMF) and the World Bank, to implement structural adjustment programmes (SAPs) in the developing world and speed up globalisation and the amalgamation of countries into the global market. By the first half of the 1980s three quarters of African countries had implemented SAPs. ${ }^{23}$

In practice this meant trade liberalisation (reduced price subsidies and currency devaluation, to bring prices in line with the world market), more flexible labour markets (removal of wage freezes and deregulation of laws protecting job security), reduced public spending (including health and education), export oriented policies to raise revenue, and export oriented infrastructure development. ${ }^{23} 24$ The effects on society that may have contributed to the HIV epidemic are:

(1) A decline in sustainable rural subsistence economies and increasing rural poverty, in combination with increased export oriented industries like mining, logging, and cash crops led to rural-urban migration, migration to the export industries, and an increase in trucking. There are, according to one estimate, at least 30 million migrant workers worldwide. ${ }^{25}$ In Cote d' Ivoire one quarter of the 12 million population are migrants, and the number is closer to $40 \%$ in the capital Abidjan. ${ }^{4}$

(2) A decline in formal sector employment, particularly the low paid/unskilled sectors that women relied on, has given rise to mass unemployment ${ }^{23}$ and greater reliance on informal sector employment, which for women (in the context of low status and poor education) has often meant prostitution.

(3) Sexually transmitted infections contribute to higher rates of HIV transmission. ${ }^{26}$ However, cuts in spending on health and education have left these countries without an adequate health infrastructure to implement 
STD treatment and HIV prevention programmes. ${ }^{24}$ For example, during the period of structural adjustment in the first half of the 1980s, per capita heath expenditure fell by $40 \%$ in Jamaica and $23 \%$ in Ghana. ${ }^{23}$

The impact of the global economics on the illegal drug trade has received little attention. Unfettered capital, especially in the wake of increased liberalisation of capital account transactions (with the abandonment of the Basle accord by Nixon in 1973), has allowed not only legal but illegal economies to transfer huge sums of money. It is estimated that US $\$ 500-1500$ million (5\% of the gross world product) is money laundered by organised crime syndicates. ${ }^{27}$ The recent scandal surrounding the $\$ 10$ billion, thought to be part of IMF loans to Russia, laundered through the Bank of New York, was merely the latest example. In 1998 the UN European headquarters estimated the combined global crime syndicates yearly income at more than $\$ 1$ million million.

The trends described above continue unabated. Urbanisation will continue at an increased rate: currently half the population of the developing world live in urban centres. By 2050 this will rise to two thirds. ${ }^{21}$ There is no evidence that the pattern of separate migration of men and women, single sex hostel living, and the resultant co-migration of CSWs will change. The World Bank's development report states "openness to the world economy will increase the volatility of urban economies and even competition among cities within the same countries." 21 This can only translate into greater vulnerability of the urban poor and further migration towards "new" economic centres.

The trend towards increasing concentration not only of capital, but also decision making through proposals like the multilateral trade agreement, enabling multinationals to reach agreements without democratic consultations, continues. Despite the poor infrastructures to implement joint sexually transmitted infections and HIV programmes, the World Bank continues to advocate a selected package of cost effective health care, with an increased reliance on the market to finance and deliver health care. ${ }^{21}{ }^{24}$ The Uruguay round of multilateral trade negotiations, completed in December 1993, strengthened both the level and enforcement of intellectual property rights, making it increasingly difficult for the developing world member states to produce cheap generic drugs during the 20 year patent period. ${ }^{28}$

While the escalating HIV epidemic becomes increasingly invisible to people living in the richer nations, the responsibility shifts to healthcare workers to advocate on behalf of the less vocal and vulnerable populations. Perhaps it is time to advocate an ethical economic policy? A global economy that confronts issues around the status of migrant labour, and the status of women? A revisitation of the effect of SAPs on the health and educational infrastructure with a commitment to providing a health infrastructure capable of implementing STD and HIV programmes? Open and accessible trade agreements that incorporate discussion about the repercussions of economic and trade policy? Modifications to intellectual property rights that would enable the world's poorer nations to benefit from recent developments in HIV treatment? While the USA's Leadership in Investment in Fighting the Epidemic (LIFE) initiative ${ }^{29}$ the international AIDS vaccine initiative, ${ }^{30}$ the success of the treatment action group, resulting in Pfizer providing free fluconazole for cryptococcal meningitis in South Africa, and the World Bank report on AIDS $^{1}$ give encouraging signals, there remains a clear need to maintain the momentum.
The interactive news page that will appear in this journal aims to report on the dynamic relation between social, economic and political policy-whether local, national, or international-and the STD/HIV epidemic and human rights..$^{19}$ Perhaps it can become a forum where players in the field can report incidents, raise questions, contribute to the ongoing debate, and maybe even someday hold the policymakers or institutions accountable for the consequences of their policies.

Mortimer Market, Gower Street, London WC1

MARYAM SHAHMANESH

bamaryjoon@yahoo.co.uk

Whittall Street Clinic, Whittall Street, Birmingham B4 6DH

MOHSEN SHAHMANESH

Mortimer Market, Gower Street, London WC1

ROB MILLER

1 World Bank. Confronting AIDS: public priorities in a global epidemic. Oxford: Oxford University Press, 1997.

2 Barnett T, Whiteside A. HIV/AIDS and development: case studies and a conceptual framework. Eur f Develop Res 1999;11.2:200-34.

3 Hunt CW. Migrant labour and sexually transmitted disease: AIDS in Africa. f Health Social Behav 1989;30:353-73.

4 Decosas J, Kane F, Anarfi JK, et al. Migration and AIDS. Lancet 1995;346: 826-8.

5 Karim QA, Karim SSA. South Africa: host to a new and emerging HIV epidemic. Sex Transm Inf 1999;75:139-41

6 Colvin M, Sharp B. Sexually transmitted infections and HIV in a rural community in the Lesotho highlands. Sex Transm Inf 2000;76:39-42.

7 Grosskurth H, Mosha F, Todd I, et al. A community trial of the impact of improved sexually transmitted disease treatment on the HIV epidemic in rural Tanzania; 2 Baseline survey results. AIDS 1995;9:927-34.

8 Sanders D, Sambo A. AIDS in Africa: the implications of economic recession and structural adjustment. Health Policy and Planning 1991;6: $157-65$

9 Mbizo MT, Machekano R, Mcfarland W, et al. Seroincidence and correlates of seroconversion in cohort of male factory workers in Harare, Zimbabwe. AIDS 1996;10:895-901.

10 Jochelson K, Mothibeli M, Leger JP. Human immunodeficiency virus and migrant labour in South Africa. Int f Health Serv 1991;21:157-73.

11 AIDS in the third world. Economist 1999 January 2:50-2.

12 Rakwar J, Lavreys L, Thompson ML, et al. Cofactors for the acquisition of HIV1 among heterosexual men: prospective cohort study of trucking company workers in Kenya. AIDS 1999;13:607-14.

13 Pais P. HIV and India:looking into the abyss. Trop Med Int Health 1996;1:295-304.

14 Tawseesak N, Mastro TD, Sangkharomya S, et al. HIV-1 infection in young men in northern Thailand. AIDS 1993;7:1233-9.

15 Bhave G, Lindan CP, Hudes ES, et al. Impact of an intervention on HIV, Sexually transmitted diseases, and condom use among sex workers in Bombay, India. AIDS 1995;9(suppl 1):S21-30

16 Ryan C, Vathiny OV, Gorbach PM, et al. Explosive spread of HIV-1 and sexually transmitted diseases in Cambodia. Lancet 1998;351:1175.

17 UNAIDS, WHO. Report on the global HIV/AIDS epidemic, fune 1998. http:// www.unaids.org/hivaidsinfo/statistics/june $98 /$ global $\% 5$ report $/ \mathrm{rep} \% 5$ report3-5.htm. (accessed on 17/04/2000.)

18 Nelson KE. The epidemiology of HIV infection among injecting drug users and other risk groups in Thailand. AIDS 1994;8:1499-500.

19 Mann J, Tarantola D. AIDS in the world II. Oxford: Oxford University Press, 1996.

20 Dehne KL, Khodakevich L, Hamers FF, S et al. The HIV/AIDS epidemic in Eastern Europe: recent patterns and trends and their implication for policy-making. AIDS 1999;13:741-9.

21 World Bank. The World Development Report 1999/2000. Entering the 21st century: the changing development landscape. World Bank, 1999.

22 UNDP. Human development report 1998. Oxford: Oxford University Press, 1998

23 Loewenson R. Structural adjustment and health policy in Africa. Int $\mathcal{F}$ Health Serv 1993;23:717-30.

24 Lurie P, Hintzen P, Lowe RA. Socioeconomic obstacles to HIV prevention and treatment in developing countries: the role of the International Monetary Fund and the World Bank. AIDS 1995;9:539-46.

25 Mabey D, Mayaud P. Sexually transmitted diseases in mobile populations. Genitourin Med 1997;73:18-22.

26 Flemming DT, Wasserheit JN. From epidemiological synergy to public health policy and practice:the contribution of other sexually transmitted diseases to the sexual transmission of HIV infection. Sex Transm Inf 1999; 75:3-17.

27 Crime without punishment. Economist 1999 Aug 28:17-19.

28 Tarabusi CC, Vickery G. Globalisation in the pharmaceutical industry II. Int f Health Serv 1998;28:281-303.

29 Watts C, Kumaranayake L. Thinking big: scaling-up HIV-1 interventions in sub-Saharan Africa. Lancet 1999;354:1429.

30 Smith R. Vaccines and medicines for the world's poorest. BMF 2000;320:952-3. 